\title{
VISAAPPLICATION IN TRAVEL AGENCIES ON BEHALF OF THE CLIENT
}

\author{
Dragana Jovanović Kuprešanin, \\ Gabrijela Lilić
}

Faculty of Business Studies and Law, Belgrade, Serbia
Correspondence:

Dragana Jovanović Kuprešanin

e-mail:

dragana.kupresanin@hotmail.com

\begin{abstract}
:
Being a tourist agent in Serbia requires having many special skills and knowledge such as planning and selling transportation, determining destination and travel dates, costs, planning and arranging itineraries, selling tour packages and assisting in resolving travel problems for travel agency's customers. An average travel agent needs to know how to apply for tourist visas to countries such as the USA, the UK, Canada or Australia, study or work permit on behalf of agency's clients and customers. Someone may think that this is an easy thing to do, but it actually isn't. This process very often requires that one needs to understand special terminology used in the instruction guides provided by the consular departments of these countries. A good travel agent is supposed to have a very good knowledge of the English language and to be able to understand and use it for specific purposes (ELSP) terminology related to tourism, economics, and very often knowing legal rules and procedures of a certain country is mandatory. This survey is based on a simple questionnaire, which is briefly illustrated in this paper. It explores various aspects linked to the learning of specific terminology in English, especially terms relevant to tourism terminology and visa application concept. We divided this survey into three main sections: essential information about knowledge that one travel agent needs to possess; we asked customers if they trust travel agents when applying for visas; we analyzed some important issues associated with the above-mentioned countries and their visa requirements. Since the process of collecting documents and understanding relevant terminology is rather complex, the authors believe that hiring a travel agent is the best solution.
\end{abstract}

Keywords:

travel agent, visa, English Language for Specific Purposes, terminology, tourist agency.

\section{INTRODUCTION}

In recent years, we have become aware that learning English for Specific Purposes (in further reading-ESP) is mandatory for many jobs related to tourism, legal matters, the European Union, economics etc. A travel agent is one who sells holiday packages and gives travel advice, books business and leisure travels for their customers. His or her role is to make travel planning easier, and to make sure that prospective clients have the best possible trip. To that end. it is necessary that one is well organised and has an eye for details. A good travel agent needs to be interested in travelling, planning and organizing and this could be an 
ideal job for those who love working with people. Being a good travel agent requires more than just booking hotel/hostels rooms or apartments or making reservation for cruises, itineraries or booking flights, solving health or travel emergency problems or even organizing excursions and special tours are also some areas that travel agents need to be good at. Knowing how to make a business plan and manage finances requires knowledge of accountancy (Heller, 2002, p. 62). Nowadays, we have so many websites that are suitable for people with basic internet skills to book their own flight or hotel or whole travel arrangement and the expected job growth for agents until 2020 is just 10 percent (if we take present situation according to computer literacy of clients) but specializing in a niche market can give the best chance for employment for future agents (Christensen, 2016). Some people are learning fast and for them it is possible "to catch" required knowledge while doing the job at the same time and if one start out on a lower position in an agency as a ticket agent and work for few years before applying for a higher or managerial position, some forms of professional training or enrolment in bachelor or master studies could be a huge advantage for certain applicants compared to other candidates. Being well trained in the field of tourism and having a good knowledge of languages is preferable. The best way to be a good travel agent is to combine an essential education with good language skills. This job requires being very well informed about the countries in demand and among of all countries like Canada, the United States, the United Kingdom and Australia are those who have the complex way of obtaining visas and clients that you may have very often are not so familiar with their visa regime and collecting documents for such purposes can be very complicated and very stressful. In that case, it is very important that clients trust the travel agent who needs to be prepared well to give all necessary information, check all the documentation and suggest if they need more supporting documents to prove that they are eligible to apply for the preferred type of visa.

\section{PURPOSE OF STUDY}

This paper aims to make contribution to better understanding of general knowledge and language skills that are essentials for travel agents if they want to provide good service to their clients. This survey is based on a simple questionnaire, which is illustrated briefly in this paper. It explores various aspects linked to learning ESP related terminology, especially terms relevant to visa application concept as a general tourist or visitor. The survey shows some main aspects as to whether people trust travel agents when they need to apply for a certain type of visa to countries such as Canada or the USA, or they like to fill in forms by themselves. How do they feel about gathering documents since gathering documents can be stressful and majority of people do not handle it well and many are not so familiar with certain requirements provided by the embassy. The travel agent who is well informed and well-organized and possesses certain level of English language knowledge will provide service on a satisfactory level and confusing terms in application forms will not represent problems to him/her.

\section{QUESTIONS RELATED TO THE SURVEY}

Three main areas are included in this research and we distributed them into three areas of questions:

1) General information about knowledge that one travel agent needs to possess;

2) We asked customers if they trust travel agents when applying for visas;

3) We analyzed some important issues related to the above-mentioned countries and their visa requirements and explained some of the most confusing English terms in their application forms.

We defined three main aspects:

Hypothesis 1

The positive aspect was defined between their level of language knowledge and their level of education and how it is recognized in the tourism field

\section{Hypothesis 2}

There is a positive issue with those clients who trust travel agents and those who would fill application form alone but they will ask the travel agent for help with gathering documents

\section{Hypothesis 3}

There is a positive outcome in the fact that hiring travel agent to help client with gathering documents and filling application forms can result in minimum risk of being refused for visa for not understanding certain terms

\section{RESEARCH RESULTS}

When we talk about the skills and knowledge of travel agents, we determine that those that one travel agent needs to possess are as follows: It is not mandatory that he/she needs to have bachelor or master's degree, but nowadays we may see that more preferable is that one agent not only possesses a university degree but also 
many other skills related to computer sciences, marketing, management and psychology. Concerning sales and marketing skills, it is recommended that the agent creates his/hers own client base and be able to grow it by attracting new perspective clients and with the use of creativity and efficiency to sell travel services to present clients and to have a personal agenda with full notes of client's travels so that one can predict future wishes of the clients concerning the countries or places they would like to visit and be prepared to suggest new itineraries and destinations they have not considered yet. Moreover, it is more than recommended for agents not to be too assertive. Given that they will need to create personal database via computer, it is more than mandatory to improve their computer literacy. The owner of the agency can always hire someone who can help to build agency's own website but if someone chooses to run the private agency and the appropriate maintenance and updating will help also to market all services and since most of clients will try to reach agent via email, it is recommended that the electronic mails are checked regularly. Buying franchise from big agencies could be a good solution but it requires more money investments (Gerber, 2010, p. 62). Otherwise, if the agent works for an agency, all this may be done by people educated to do that except for emails checking, but if someone decided to be an independent agent, he/she will need to possess at least the basic knowledge of bookkeeping and software for these purposes and possess good math skills that can help calculating income and expenses. Since future agency clients may travel all around the world, the knowledge of geography can be more than useful as well as having excellent communication skills. Acting like no self-assertive person when trying to persuade clients about the services of the agency is more than recommended. When we talk about being a good psychologist it does not mean that one need to have a diploma in the field of psychology, but he/ she needs to be familiar with the human nature and to know how to handle those who are too forceful, insecure or maybe disappointed with certain services. When planning itineraries, it is compulsory to think logically and to act on behalf of clients in a very honest and fair way. In order to be able to arrange travels to other countries and to understand all the required points, it is important that foreign language fluency is on a higher level (Christensen, 2016). English is usually essential in most of cases and now we have English for Specific Purposes related to tourism field. To finish one ESP course you need to be at least at B1 Level according to CEFR (Common European Framework References) and these courses are like training-based programs and they usually deal with the subjects associated with tourism and hospitality industries and there is abundance of literature connected to this terminology and it enables students to be good in their overall English skills based on communication. Thanks to that, they are able to use English in their workplace and can even advance their knowledge and understanding in many different areas, not only tourism and hospitality, but also other similar fields cooperating with many people from various countries. The agent needs to have the ability to behave well in multicultural environment. Well-prepared candidates are able to participate in job interviews in English and these lessons are usually based on the subjects such as tour guiding, English skills for dealing with booking flights, making hotel reservations and taking care of customer satisfaction, managing customers and staff, writing resumes and application letters, organizing marketing and promotion, handling bookings and reservations. All this makes one agent more competitive in the labor market.

All participants in the survey voluntary participated and the responses provided were anonymous. A total number of participants was 36 . The citizens of the Republic of Serbia do not need visas for countries in the European Union and they can stay up to three months, so the questionnaire was distributed via Facebook and it assessed customers' opinion about travel agencies and whether they trust travel agents when applying for visas for countries like Canada and the USA. The results showed that $76 \%$ of all participants were those who mostly travel to Canada, $21 \%$ were those traveling to the USA, and the rest of the population were those traveling to any other country, as is illustrated in the graph below.

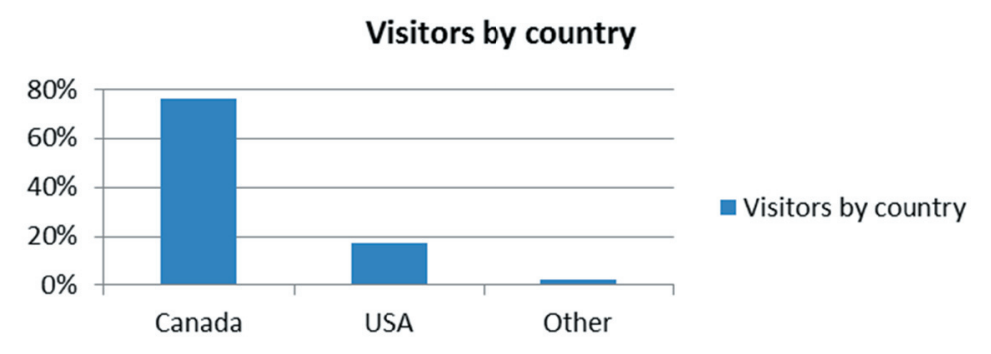

Figure 1. Percentage of people traveling to Canada, USA and other countries

The reasons why people travel to the above-mentioned countries are mostly for visiting family members or friends and many of them are going to work or study there. $72 \%$ of all participants in this survey said that they trust travel agents and they believe that they will fill in the visa application forms better than they are able to do 
as applicants. Namely, $24 \%$ of all consider themselves as good with language skills and they will fill in the forms but they would ask for help when gathering the documents, since this can be time consuming and one is not capable to deal alone with that, asking someone who is well informed is an advantage and only $4 \%$ of all participants said that they do not trust travel agents and they will take all necessary steps alone without any assistance. These people mostly had bad experience with these embassies in the past.

\section{Trust travel agents when applying for visa}

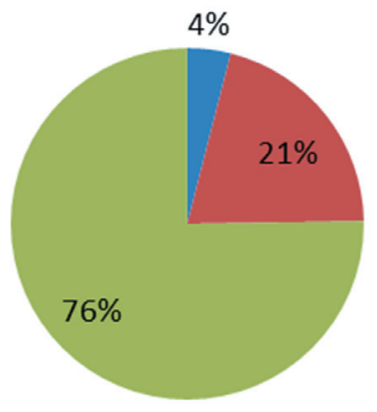

not trust agents

ask for help

m trust agent

Figure 2. Showing how many people trust travel agents

When applying for a visa to Canada, the USA, the UK or Australia, applicants need to prepare similar documents related to their purpose of travel. Such amount of documents may confuse someone wishing to apply and this research showed that they will rather ask for help than fill that forms by themselves. Terms like eligible, nationality or country of origin, family name, surname or given name may confuse one, so $72 \%$ of participants in this survey agree that they would rather trust travel agents than do all alone, which could be consider as a good aspect among clients. Their trust tell us that one travel agent in Serbia is well educated and well prepared and that the percentage of those who got their visas after receiving agency's assistance are more than on a satisfactory level. That customers trust travel agents even when they are capable of filling those forms alone is confirmed by $24 \%$ of all participants in this survey, while $4 \%$ of those who do not travel agents are maybe those who were refused once by some embassy (CIC, 2016). In the field of tourism, filling certain forms and making phone calls is mandatory. Luckily, all updates related to a visa regime of the given country could be found on the official websites of these embassies (Harding, 2009, pp. 38-39).

\section{CONCLUSION}

The research results have helped us to analyze some important issues related to the above-mentioned countries and their visa requirements and attempted to explain some of the most confusing English terms in their application forms. We determined that one travel agent needs to possess various skills from marketing to advance knowledge of the English language associated with the specific terminology in the field of tourism, law, economics etc. In order to successfully complete one ESP course, one needs to be at least at B1 Level according to CEFR (Common European Framework References), and this course usually deals with the references connected to the industries that cover hospitality and tourism through different magazines, books, websites and other useful materials relevant to this terminology. All this can help the students to improve their English skills affiliated with good knowledge of speaking, reading, writing, listening and use of language. Besides that, people trust travel agents and they would let them fill in the application forms and gather documents on behalf of them. Even those who would fill in the forms alone would ask for help when gathering documents. There are many terms related to application forms, but we mentioned those most frequent that lead to misunderstanding. This research showed that the majority of clients will rely on the travel agent and his or her knowledge and even if they are able to fill certain forms, they will ask advice from them or ask for help with collecting papers. More than a few people will do all by themselves because they do not trust agents, or we may say they are suspicious, probably because of their bad experience with certain embassy in the past. A travel agent is always here to give the appropriate advice to clients, be patient even in stressful situations and when he or she needs to deal with difficult people. We hope that this paper will help travel agents on their path towards building successful careers and that they may think about finishing some bachelor or master's degree studies since that could be useful for their further promotion as well as about improving their English language skills. Having visas from countries like Canada, the USA, Australia or the UK is considered by these countries as a privilege, so an applicant needs to be well-prepared, with correctly filled forms and information that could help them obtain certain visas.

\section{REFERENCES}

Heller, R. (2002). Manager's handbook: Everything you need to know about how business and management work. London: DK Pub. 
Christensen, M. (2016). What skills does one need to be an travel agent? Retrieved August 29, 2016. http://work. chron.com/skills-one-need-travel-agent-16110.html

Gerber, M.E. (2010). Mit o preduzetništvu : zašto većina malih privatnih firmi ne uspeva i šta učiniti u vezi sa tim. Beograd: Čarobna knjiga.

Christensen, M. (2016). What Skills Does One Need to Be an Travel Agent? Retrieved August 10, 2016 from http://work.chron.com/skills-one-need-travelagent-16110.html
CIC. (2016). Citizenship and Immigration Canada. Retrieved August 01, 2016 from http://www.cic.gc.ca/ english/information/applications/guides/

Harding, K.(2009). Going International: English for Tourism. Oxford: Oxford University Press. 